\title{
O CRÉDITO ORÇAMENTÁRIO COMO DIRETRIZ PARA A FIXAÇÃO DA VIGÊNCIA DOS CONTRATOS ADMINISTRATIVOS: O PARADOXO ENTRE OS RESTOS A PAGAR E O ENDIVIDAMENTO PÚBLICO
}

\author{
Evandro Maciel Barbosa \\ Mestre em Direitos Fundamentais (FDV - Vitória-ES). \\ Doutorando em Direito Financeiro - USP \\ Procurador do Estado do Espírito Santo.
}

\section{- SUMÁRIO}

Introdução - 1. O contrato administrativo: 1.1 Conceito e regime jurídico; $1.2 \mathrm{O}$ crédito orçamentário e o princípio da anualidade do orçamento; $1.3 \mathrm{O}$ artigo 57 e a vigência temporal dos contratos administrativos; 1.4 As exceções à vigência do crédito orçamentário; 1.4.1 O Plano Plurianual (inciso I); 1.4.2 Os serviços contínuos (inciso II); 1.4.3 As demais hipóteses dos incisos IV e V - 2. A execução do orçamento e os restos a pagar: 2.1 Dos restos a pagar; 2.1.1 Dos restos a pagar e as disposições do Decreto Federal n. 93.872/1986; 2.1.2 O carry-over orçamentário e os riscos do endividamento público - Considerações finais - Referências. 


\section{INTRODUÇÃO}

Em tempos em que governança pública e a consolidação da ideia de boa administração pública como direito fundamental ${ }^{1}$ dão a tônica da moderna gestão governamental, a recorrência à premissa do "orçamento equilibrado" tem sido a pedra de toque nos debates sobre a sustentabilidade fiscal.

A partir da ideia de equilíbrio e sustentabilidade fiscais, o presente artigo busca contribuir para o debate referente ao prazo de vigência dos contratos administrativos, cuja disciplina encontra-se no artigo 57 da Lei n. 8.666, de 21 de junho de 1993, que, por sua vez, regulamenta o inciso XXI do artigo 37 da Constituição Federal de $1988^{2}$, e sua relação com a flexibilização da rigidez orçamentária por meio do carry-over, especificamente os restos a pagar (unpaid commitments) e os seus reflexos no endividamento público e nas políticas de investimentos.

$\mathrm{Na}$ medida em que o artigo 57 mencionado estabelece, como regra, em seu caput, que a duração dos contratos públicos da Administração ficará adstrita à vigência de seus respectivos créditos orçamentários, ressalvadas as exceções em seus incisos, impõe-se, na interpretação da referida norma, lançar uma luz interdisciplinar que envolva tanto as premissas do Direito Administrativo, especialmente sob seu enfoque contratual, quanto o Direito Financeiro, autêntico mecanismo jurídico sistematizador da atividade financeira do Estado, mormente o

1 Segundo Juarez Freitas: “(...) na tomada das decisões administrativas, o Estado Constitucional precisa zelar pelo isento dever de oferecer legítimas e boas razões de fato e de direito. (...) Pois bem, a legitimidade (conformação da tábua axiológica da Constituição e seus objetivos fundamentais, especialmente os arrolados no art. $3^{\circ}$ ) pressupõe a observância dos limites finalísticos estatuídos pelo vinculante novo papel do Estado, em termos de respeito ao direito fundamental à boa administração (...). Pressupõe, nessa linha, a geração de ambiente institucional favorável a parceiros produtivos, com a redução dos entraves oriundos da quebra reiterada da confiança. E mais: pressupõe, sem tardar, a contínua sinergia entre as políticas públicas e o estabelecimento pactuado de metas e resultados. Pressupõe, enfim, a criatividade, a inovação e a sólida resistência às pressões espúrias do imediatismo, além da translucidez e controle social em matéria de orçamento público" (Discricionariedade administrativa e o direito fundamental à boa administração pública. 2. ed. São Paulo: Malheiros, 2009, p. 20-21) (grifos do original).

2 Art. 37. (...) XXI - ressalvados os casos especificados na legislação, as obras, serviços, compras e alienações serão contratados mediante processo de licitação pública que assegure igualdade de condições a todos os concorrentes, com cláusulas que estabeleçam obrigações de pagamento, mantidas as condições efetivas da proposta, nos termos da lei, o qual somente permitirá as exigências de qualificação técnica e econômica indispensáveis à garantia do cumprimento das obrigações. 
planejamento público governamental e seu instrumental de operacionalização: o planejamento orçamentário da Administração Pública ${ }^{3}$.

Nesse passo, falar em contrato administrativo é falar em despesa pública; e falar em despesa pública é falar em orçamento público, que tem sua fonte na Constituição da República, delineado, a princípio, entre os seus artigos 165 a 1694. Segundo o magistério de Torres ${ }^{5}$,

A disciplina básica da receita e da despesa estabelece-a a Constituição, que deve estampar os princípios e as normas que tratem simultaneamente de ambas as faces da mesma moeda - as entradas e os gastos públicos. São de natureza veramente constitucional o prever o equilíbrio orçamentário, o distribuir a competência para autorizar a cobrança de impostos e a realização de gastos, o exigir a periodicidade do controle legislativo e o estabelecer as diretrizes para a redistribuição de rendas.

Trata-se de um sistema de normas de fonte constitucional e que se desdobra em normas legais que regulamentam o orçamento público, formatando o sistema orçamentário nacional.

Essa sistematização tem sua relevância destacada pelo Mestre lusitano Sousa Franco ${ }^{6}$, ao alertar que o orçamento só pode ser compreendido como "uma forma de limitação de poderes dos órgãos do Estado se a sua execução for sujeita a regras estritas, condicionando a Administração ao respeito da legalidade em geral

3 Segundo José Mauricio Conti, “vê-se ser perfeitamente admissível, e compreensível de forma suficientemente clara, a concepção de planejamento com esses dois significados e respectivos enfoques, a saber, e em parte reitero e ratifico o que já foi exposto: a existência de um planejamento econômico governamental, com maior densidade axiológica, que volta suas preocupações à definição dos rumos do Estado, com conteúdo de caráter essencialmente nacional; e um planejamento orçamentário da Administração Pública, cujas preocupações são de caráter basicamente instrumental, voltadas a materializar as decisões políticas em medidas concretas que permitam conduzir a Administração Pública de forma coesa e coordenada em direção aos rumos estabelecidos" (O planejamento orçamentário da administração pública no Brasil. Tese de Titularidade. Faculdade de Direito da USP. São Paulo: edição do autor, 2017, p. 68).

4 Colhem-se em outros tópicos constitucionais, da mesma forma, regras orçamentárias prescritas fora do referido sistema, mas que não se pode negar suas integrações, a exemplo das normas de controle de execução orçamentária previstas nos artigos 70 a 75, no artigo 31, referente à fiscalização orçamentária dos municípios, bem como o artigo 127, referente ao orçamento do Ministério Público, dentre outras.

5 TORRES, Ricardo Lobo. O orçamento na Constituição. Rio de Janeiro: Renovar, 1995, p. 1.

6 FRANCO, António L. de Sousa. Finanças públicas e direito financeiro. 4. ed. Coimbra: Almedina, 2015, v. I e II, p. 296. 
e do orçamento em especial, e também se houver formas sofisticadas de controlo da execução orçamental”.

Não é por acaso, portanto, que a licitação e seu consequente lógico, o contrato administrativo, também derivam de matriz constitucional imposta ao Poder Público, conforme apontado na norma do artigo 37, XXI, retromencionado, pois, além de ter por finalidade a busca da proposta comercial mais vantajosa para a Administração Pública ${ }^{7}$, integram esse organizado sistema de planejamento voltado à realização da despesa pública.

Marcus Abraham ${ }^{8}$, de forma percuciente, ressalta que o processo de execução da despesa pública

(...) é composto por uma etapa prévia, em que se identifica a necessidade de licitação (concorrência, tomada de preços, convite, concurso e leilão), seguida de três etapas do procedimento propriamente dito, que contemplam o empenho, a liquidação e a ordem de pagamento.

A etapa prévia possui o objetivo de verificar se para a realização daquela despesa pública específica será necessária a realização prévia de uma licitação. Se confirmada a necessidade da sua realização, esta deverá ser implementada como condição de continuidade do processo de realização da despesa pública. Isso porque, segundo a própria Constituição Federal (art. 37, inciso XXI), ressalvados os casos especificados na legislação, as obras, serviços, compras e alienações serão contratados mediante processo de licitação pública que assegure igualdade de condições a todos os concorrentes, garantindo-se à Fazenda Pública um produto ou serviço de melhor qualidade, com o menor custo possível [destaque no original].

Segundo, ainda, o magistério de Leite?:

Se há rigorosidade para o ingresso de recursos públicos, a fim de que ele observe a estrita legalidade, maior rigorosidade ocorre quando o tema é o

7 Nas palavras de Celso Antônio Bandeira de Mello, a "licitação - em suma síntese - é um certame que as entidades governamentais devem promover e no qual abrem disputa entre os interessados e com elas travar determinadas relações de conteúdo patrimonial, para escolher a proposta mais vantajosa às conveniências públicas. Estriba-se na ideia de competição, a ser travada isonomicamente entre os que preenchem os atributos e aptidões necessários ao bom cumprimento das obrigações que se propõem assumir" (Curso de direito administrativo. 17. ed. São Paulo: Malheiros, 2004, p. 483).

8 ABRAHAM, Marcus. Curso de direito financeiro brasileiro. 4. ed. Rio de Janeiro: Forense, 2017, p. 224.

9 LEITE, Harrison. Manual de direito financeiro. 6. ed. Salvador: Juspodivm, 2017, p. 314. 
gasto público. É que a legislação brasileira traça todo um procedimento, que se inicia com a compatibilização do gasto com os desígnios constitucionais, perpassado pelos PPA, LDO e LOA, para, em observância às normas impostas pelo direito administrativo, principalmente quanto à lei de licitações (Lei n. 8.666/93), efetuar-se o gasto real (...).

Evidente, portanto, o papel do procedimento licitatório como parte integrante de todo um sistema de planejamento voltado à realização da despesa pública ${ }^{10}$. Enquanto procedimento, a licitação se apresenta como o antecedente necessário do contrato administrativo, constituindo este último, por sua vez, o consequente lógico da licitação.

Não há como conceber, por exemplo, a realização de despesas de custeio como aquisição de material de consumo ou contratação de serviços de terceiros, como limpeza ou serviço de engenharia, assim como realização de despesas de capital, como construção de obras públicas ou aquisição de material permanente, apenas para citar algumas hipóteses elencadas no artigo 13 da Lei n. 4.320/1964, sem atrelá-las ao principal instrumento para suas concretizações: o contrato administrativo.

E, partindo dessa premissa, observam-se, no âmbito da Lei n. 8.666/1993, diversas normas que formam um microssistema orçamentário que só reforça o papel supradestacado, apontando a relevância do procedimento licitatório como instrumento de controle da realização da despesa pública. Podem-se apontar como exemplos tanto o artigo $7^{\circ}, \mathbb{S} 2^{\circ}$, III, ao estabelecer que as obras e serviços só poderão ser licitados quando "houver previsão de recursos orçamentários que assegurem o pagamento das obrigações decorrentes de obras ou serviços a serem executadas no exercício financeiro em curso, de acordo com o respectivo cronograma”, ou previstos no Plano Plurianual (inciso IV), quanto o artigo 14, referente às compras, estabelecendo que estas não poderão ser efetuadas "sem a adequada caracterização de seu objeto e indicação dos recursos orçamentários para seu pagamento, sob pena de nulidade do ato e responsabilidade de quem lhe tiver dado causa”.

Cite-se, outrossim, o artigo 38, que, ao dispor sobre a instauração do procedimento licitatório, impõe que este deva ser "iniciado com a abertura de processo administrativo, devidamente autuado, protocolado e numerado, contendo a autorização respectiva, a indicação sucinta de seu objeto e do recurso próprio para a

10 Mesmo porque o artigo 70 da Lei n. 4.320/1964 já previa que a "aquisição de material, o fornecimento e a adjudicação de obras e serviços serão regulados em lei, respeitado o princípio da concorrência”, norma esta inserida no Título VI (Da Execução do Orçamento), Capítulo III (Da Despesa). 
despesa". Por fim, o artigo 40, que, ao elencar os requisitos que devem conter os editais de licitação, exige, no inciso XIV, $b$, dentre outras condições para o pagamento da obrigação, a previsão de "cronograma de desembolso máximo por período, em conformidade com a disponibilidade de recursos financeiros".

Constituindo o contrato administrativo, mais especificamente o crédito orçamentário como critério para fixação de seu prazo de vigência, objeto desse estudo, passa-se à sua análise no tópico seguinte.

\section{O CONTRATO ADMINISTRATIVO}

\subsection{Conceito e regime jurídico}

Dentre as inúmeras normas de caráter conceitual insertas na Lei n. 8.666/1993, o parágrafo único do artigo $2^{\circ}$ define contrato administrativo, para os fins da referida Lei, como "todo e qualquer ajuste entre órgãos ou entidades da Administração Pública e particulares, em que haja um acordo de vontades para a formação de vínculo e a estipulação de obrigações recíprocas, seja qual for a denominação utilizada".

Na concepção de Di Pietro ${ }^{11}$,

(...) a expressão contrato administrativo é reservada para designar tão somente os ajustes que a Administração, nessa qualidade, celebra com pessoas físicas ou jurídicas, públicas ou privadas, para a consecução de fins públicos, segundo regime jurídico de direito público (grifo do original).

Por sua vez, Bandeira de Mello ${ }^{12}$ define o contrato administrativo nos seguintes termos:

(...) é um tipo de avença travada entre a Administração e terceiros na qual, por força de lei, de cláusulas pactuadas ou do tipo de objeto, a permanência do vínculo e as condições preestabelecidas assujeitam-se a cambiáveis imposições de interesse público, ressalvados os interesses patrimoniais do contratante privado.

Um dos aspectos mais relevantes a caracterizar os contratos administrativos reside no regime jurídico de suas normas, o regime jurídico administrativo, ou de direito público, a que se submetem tais instrumentos, conferindo à Administração

11 DI PIETRO, Maria Sylvia Zanella. Direito administrativo. 29. ed. Rio de Janeiro: Forense, 2016, p. 297.

12 BANDEIRA DE MELLO, Celso Antônio. Curso de direito administrativo. 17. ed. São Paulo: Malheiros, 2004, p. 573-574. 
Pública contratante prerrogativas contratuais que se materializam nas chamadas cláusulas exorbitantes, em sua maioria previstas no artigo 58 da Lei n. 8.666/1993, a exemplo da modificação e rescisão unilaterais, prerrogativas que se justificam em função da finalidade pública que norteia os contratos.

Decorre também do regime jurídico administrativo a imperatividade de que conste nos contratos administrativos as chamadas cláusulas necessárias ou essenciais, descritas no artigo 55 da Lei n. 8.666/1993, dentre elas aquela prevista no inciso V, qual seja, a indicação do "crédito pelo qual correrá a despesa, com a indicação da classificação funcional programática e da categoria econômica”.

A classificação funcional programática fornece informações das realizações do Governo por meio de um conjunto de programas, desdobrados em ações, ao passo que o critério classificatório por categoria econômica informa os efeitos que a despesa pública tem na atividade macroeconômica ${ }^{13}$, nos termos do artigo 12 da Lei n. 4.320/1964, critérios também evidenciados no caput do artigo $2^{\circ}$ da mesma Lei ${ }^{14}$.

Daí se afirma que a natureza da despesa pública possui relevantes reflexos sociais e econômicos. Slomski e Peres ${ }^{15}$ apontam que "as diferentes naturezas da despesa pública executadas pelo Estado podem ter graus distintos de interferência e propagação econômica ajudando a explicar o crescimento ou a estagnação de um país”.

Observa-se, portanto, que o crédito orçamentário, além de nortear o prazo de vigência do contrato administrativo, deve ser descrito, expressamente, como conteúdo de cláusula própria, o que permite a verificação da adequação do objeto contratual (despesa) com o crédito legal que o autoriza. É a premissa de que se parte, qual seja, de que o regime jurídico administrativo é um regime de prerrogativas administrativas, mas também de sujeições da Administração e contratado.

\subsection{O crédito orçamentário e o princípio da anualidade do orçamento}

De início, cumpre trazer o conceito de crédito orçamentário, de forma a se alcançar melhor compreensão do contexto da norma do artigo 57 da Lei n. 8.666/1993.

${ }^{13}$ FEIJÓ, Paulo Henrique; AlbUQUerQUe, Claudiano; MEdeIROS, Márcio. Gestão de finanças públicas. 3. ed. Brasília: Gestão Pública, 2013, v. I, p. 247 e 250.

14 "Art. $2^{\circ}$ A Lei do Orçamento conterá a discriminação da receita e despesa de forma a evidenciar a política econômica financeira e o programa de trabalho do Governo, obedecidos os princípios de unidade universalidade e anualidade" (grifo nosso).

15 SLOMSKI, Valmor; PERES, Ursula Dias. As despesas públicas no orçamento: gasto público eficiente e a modernização da gestão pública. In: CONTI, José Mauricio; SCAFF, Fernando Facury (coord.). Orçamentos públicos e direito financeiro. São Paulo: RT, 2011, p. 915. 
Faria ${ }^{16}$ esclarece que "os créditos representam as categorias classificatórias de acordo com as quais a despesa é discriminada, de forma mais ou menos detalhada, no Orçamento".

Giacomoni ${ }^{17}$, por sua vez, define os créditos orçamentários diferenciando-os das dotações orçamentárias, senão vejamos:

A lei orçamentária é organizada na forma de créditos orçamentários, aos quais estão consignadas dotações. Em consequência da imprecisão com que são utilizadas na legislação, é comum o emprego das expressões crédito orçamentário e dotação como sinônimos. Na realidade, o crédito orçamentário é constituído pelo conjunto de categorias classificatórias e contas que especificam as ações e operações autorizadas pela lei orçamentária. No âmbito do orçamento federal brasileiro, a partir do exercício de 2000, o crédito orçamentário individualizado compreende o seguinte conjunto de categorias classificatórias presentes na lei orçamentária: Grupo de Despesa, Identificador de Uso, Fonte de Recursos, Modalidade de Aplicação, Categoria Econômica, Subtítulo, Projeto ou Atividade ou Operação Especial, Programa, Função, Unidade Orçamentária e Órgão. Por seu turno, dotação é o montante de recursos financeiros com que conta o crédito orçamentário.

Enfim, o crédito orçamentário refere-se à autorização prevista na lei do orçamento para que determinada despesa seja realizada, ao passo que a dotação são os recursos financeiros disponibilizados para a referida despesa, ou seja, o crédito orçamentário contém dotações. Salienta Silva ${ }^{18}$ :

Créditos orçamentários - São os previstos no orçamento anual para ocorrerem às despesas previstas para a execução dos programas. São estabelecidos em favor das unidades orçamentárias, que são as unidades administrativas (em geral, ao nível departamental) responsáveis pela execução dos programas. As dotações significam parcelas desse crédito destinadas para alguma despesa ou para a despesa de algum serviço, para algum projeto ou atividade e até para algum órgão. O termo dotação orçamentária praticamente absorveu o sentido que cabia à palavra verba. Antes dotação só se referia à importância dos recursos orçamentários designados para uma repartição. Hoje o vocábulo é empregado naquele sentido também, mas

\footnotetext{
16 FARIA, Rodrigo Oliveira de. Natureza jurídica do orçamento e flexibilidade orçamentária. 2009. 287 f. Dissertação (Mestrado) - Faculdade de Direito, USP, São Paulo, 2009, p. 132.

17 GIACOMONI, James. Orçamento público. 17. ed. São Paulo: Atlas, 2017, p. 321.

18 SILVA, José Afonso da. Orçamento-programa no Brasil. São Paulo: RT, 1973, p. 313.
} 
especialmente tem o sentido de recursos orçamentários consignados para qualquer fim.

A anualidade constitui princípio intrínseco à vigência dos créditos orçamentários e que, segundo Burkhead ${ }^{19}$, “exige que os orçamentos sejam apresentados cada ano e que se refiram a apenas um ano fiscal”. Significa que a vigência dos referidos créditos, tendo sido instituídos no âmbito da lei orçamentária anual, estende-se apenas pelo lapso temporal de um ano, surgindo o referido princípio da ideia de controle parlamentar sobre os atos do Poder Executivo ${ }^{20}$.

Viana $^{21}$ já chamava a atenção para o fato de que

Todos os indivíduos e todos os povos procuram delimitar, dentro de um determinado lapso de tempo, o exame de suas realizações, para que possam aplicar o senso da medida à sua própria capacidade criadora. Quase todos os povos escolhem o período de tempo correspondente a um ano como o ideal para dentro dele serem delimitadas as estimativas do respectivo orçamento. (...) No Brasil, sempre se adotou a anualidade. O ano financeiro, atualmente, começa em 1 de janeiro e termina em 31 de dezembro.

De fato, no Brasil, o ano orçamentário, ou exercício financeiro, período em que vigem a lei orçamentária e os créditos nela estabelecidos, nos moldes do artigo 34 da Lei n. 4.320/1964, coincide com o ano civil, ou seja, vigora de $1^{\circ}$ de janeiro a 31 de dezembro, estando o princípio da anualidade expressamente previsto no caput do artigo $2^{\circ}$ da Lei n. 4.320/1964, retrocitado.

Daí o posicionamento sustentado por determinados doutrinadores, de que o caput do artigo 57 da Lei n. 8.666/1993, ao atrelar, como regra, o prazo do contrato administrativo à vigência do seu respectivo crédito orçamentário, nada mais faz do que observar a "anualidade" inerente aos orçamentos.

\subsection{0 artigo 57 e a vigência temporal dos contratos administrativos}

Estabelece o artigo 57 da Lei n. 8.666/1993, que disciplina o prazo de vigência dos contratos administrativos:

19 BURKHEAD, Jesse. Orçamento público. Rio de Janeiro: FGV, 1971, p. 140.

20 Segundo Fonrouge, “contribuyeron a su afianzamiento argumentos de orden político, ya que el sistema robustecía la facultad parlamentaria de controlar al ejecutivo, de modo tal que la práctica iniciada bajo forma de voto anual del impuesto, se trasformó em um médio efectivo de conocer, vigilar y limitar la acción general del gobierno em la democracia clássica” (Derecho financiero. 2. ed. Buenos Aires: Depalma, 1970, v. I, p. 153).

21 VIANA, Arizio de. Orçamento brasileiro. 2. ed. Rio de Janeiro: Edições Financeiras, 1950, p. 91-92. 
Art. 57. A duração dos contratos regidos por esta Lei ficará adstrita à vigência dos respectivos créditos orçamentários, exceto quanto aos relativos:

I - aos projetos cujos produtos estejam contemplados nas metas estabelecidas no Plano Plurianual, os quais poderão ser prorrogados se houver interesse da Administração e desde que isso tenha sido previsto no ato convocatório;

II - à prestação de serviços a serem executados de forma contínua, que poderão ter a sua duração prorrogada por iguais e sucessivos períodos com vistas à obtenção de preços e condições mais vantajosas para a administração, limitada a sessenta meses;

III - (Vetado).

IV - ao aluguel de equipamentos e à utilização de programas de informática, podendo a duração estender-se pelo prazo de até 48 (quarenta e oito) meses após o início da vigência do contrato.

V - às hipóteses previstas nos incisos IX, XIX, XXVIII e XXXI do art. 24, cujos contratos poderão ter vigência por até 120 (cento e vinte) meses, caso haja interesse da administração. (Incluído pela Lei n. 12.349, de 2010)

\1 1o Os prazos de início de etapas de execução, de conclusão e de entrega admitem prorrogação, mantidas as demais cláusulas do contrato e assegurada a manutenção de seu equilíbrio econômico-financeiro, desde que ocorra algum dos seguintes motivos, devidamente autuados em processo:

I - alteração do projeto ou especificações, pela Administração;

II - superveniência de fato excepcional ou imprevisível, estranho à vontade das partes, que altere fundamentalmente as condições de execução do contrato;

III - interrupção da execução do contrato ou diminuição do ritmo de trabalho por ordem e no interesse da Administração;

IV - aumento das quantidades inicialmente previstas no contrato, nos limites permitidos por esta Lei;

$\mathrm{V}$-impedimento de execução do contrato por fato ou ato de terceiro reconhecido pela Administração em documento contemporâneo à sua ocorrência;

VI - omissão ou atraso de providências a cargo da Administração, inclusive quanto aos pagamentos previstos de que resulte, diretamente, impedimento ou retardamento na execução do contrato, sem prejuízo das sanções legais aplicáveis aos responsáveis.

\2ำ Toda prorrogação de prazo deverá ser justificada por escrito e previamente autorizada pela autoridade competente para celebrar o contrato.

\3ํ́ vedado o contrato com prazo de vigência indeterminado.

\4 4 - Em caráter excepcional, devidamente justificado e mediante autorização da autoridade superior, o prazo de que trata o inciso II do caput deste artigo poderá ser prorrogado por até doze meses. 
Ao estabelecer como regra geral no caput que o prazo de duração contratual ficará adstrito à vigência dos respectivos créditos orçamentários, a norma sob exame revela natureza eminentemente orçamentária, típica norma de Direito Financeiro.

Assim reconhece Pereira Junior ${ }^{22}$, ao afirmar que "a norma é de direito financeiro. Como tal submete-se às regras que informam o exercício da competência concorrente entre União, Estados e Distrito Federal (CF/88, art. 24, I)".

E acrescenta o ilustre administrativista que, como os créditos orçamentários são anuais, ânua também seria a duração dos contratos, ou seja, a regra legal ora sob exame nada mais faz do que observar o princípio da anualidade orçamentária, como já demonstrado anteriormente.

Justen Filho ${ }^{23}$ também reforça o caráter orçamentário da norma do artigo 57 e, no tocante às exceções previstas em seus incisos, esclarece que estas “(...) não se relacionam propriamente à natureza ou à importância do objeto da contratação. A disciplina adotada se relaciona com questões orçamentárias, pura e simplesmente".

E, como já aventado, é justamente em função da anualidade dos créditos orçamentários que diversos juristas atrelam a duração do contrato administrativo ao exercício financeiro, período em que vige a lei orçamentária e, por corolário lógico, os créditos orçamentários. Nesse sentido, preconiza Di Pietro ${ }^{24}$ :

Como o exercício financeiro coincide com o ano civil (art. 34 da Lei 4.320/1964), os créditos normalmente têm essa vigência, a não ser que previstos no Plano Plurianual. Para evitar a celebração de contratos que ultrapassem o exercício financeiro, com comprometimento do orçamento do ano subsequente, a lei quis fazer coincidir a duração dos contratos com o término do exercício financeiro, só admitindo, para os projetos, prazo superior, quando estejam previstos no Plano Plurianual. Com isso, evita-se a realização de obras e serviços não planejados, que possam acarretar ônus superiores às possibilidades orçamentárias.

Observa-se que a eminente administrativista aponta como fundamento à regra da vinculação da vigência contratual ao exercício financeiro a preocupação

22 PEREIRA JUNIOR, Jessé Torres. Comentários à lei das licitações e contratações da administração pública. 8. ed. Rio de Janeiro: Renovar, 2009, p. 649.

${ }^{23}$ JUSTEN FILHO, Marçal. Comentários à lei de licitações e contratos administrativos. 16. ed. São Paulo: RT, 2014, p. 948.

24 DI PIETRO, Maria Sylvia Zanella. Direito administrativo, cit., p. 310. 
com um possível comprometimento do orçamento do exercício financeiro seguinte àquele em que contraída a despesa ${ }^{25}$, fora das exceções dos incisos, não podendo, dessa forma, a duração do contrato extrapolar a data de 31 de dezembro. No mesmo sentido, Pereira Junior ${ }^{26}$ :

Os créditos orçamentários são anuais; em cada contrato é obrigatória a inserção de cláusula que identifique o crédito orçamentário que responderá pelas respectivas despesas (art. 55, V); logo, como regra geral, a duração dos contratos também será ânua.

O princípio da anualidade do orçamento público é dos mais antigos do direito financeiro. Na Constituição Federal de 1988 encontra-se, implicitamente, nos arts. 48 , II, 165 , III e $\mathbb{5} 5^{\circ}$, e 166 , todos referindo-se a orçamentos anuais. A Lei federal n. 4.320/64, que consolida as normas gerais de direito financeiro brasileiro, estabelece, em seu art. 34, que o "exercício financeiro coincidirá com o ano civil”. Por conseguinte, os contratos da Administração Pública brasileira devem acomodar-se a tais termos inicial e final do exercício financeiro, que são os mesmos do ano civil $\left(1^{\circ}\right.$ de janeiro a 31 de dezembro).

E, ainda, segundo Niebuhr ${ }^{27}$ :

A regra a respeito da duração dos contratos está prescrita no caput do art. 57 da Lei n. 8.666/93, cujo texto prescreve que ela, a duração dos contratos administrativos, deve ser adstrita à vigência dos respectivos créditos orçamentários. O crédito orçamentário coincide com o ano civil, logo abrange o período que se estende de $1^{\circ}$ de janeiro a 31 de dezembro.

Ou seja, a duração do contrato administrativo pode estender-se por qualquer prazo dentro do referido intervalo. Por exemplo, pode-se firmar contrato cuja duração estenda-se de $1^{\circ}$ de janeiro a 31 de dezembro, de 20 de janeiro a 10 de março, de 17 de março a 25 de outubro, de 26 de outubro a 2 de dezembro, etc. Pode-se firmar contrato com qualquer prazo desde que a duração dele inicie-se a partir de $1^{\circ}$ de janeiro e desde que ela não vá para além de 31 de dezembro. Pode-se afirmar que o prazo fatal, em regra, para a duração dos contratos administrativos é o dia 31 de dezembro.

(...) Outra inconveniência é que os contratos relativos às aquisições devem prever prazo de entrega até o dia 31 de dezembro. Por exemplo, a Adminis-

${ }^{25} \mathrm{E}$, pelo mesmo fundamento, o $\mathbb{3} 3^{\circ}$ do mesmo artigo 57 veda o contrato com prazo de vigência indeterminado.

26 PEREIRA JUNIOR, Jessé Torres. Comentários à lei das licitações e contratações da administração pública. 8. ed. Rio de Janeiro: Renovar, 2009, p. 649.

27 NIEBUHR, Joel de Menezes. Licitação pública e contrato administrativo. 2. ed. Belo Horizonte: Fórum, 2011, p. 724-725. 
tração firma contrato para a compra de móveis para escritório. O contratado deve entregar os móveis até o dia 31 de dezembro, porque a duração do contrato administrativo é em tal termo limitada. A Administração, portanto, não poderia firmar contrato de fornecimento em dezembro se o prazo de entrega ultrapassar 31 de dezembro, sob pena de violar o caput do art. 57 da Lei n. 8.666/93.

Por fim, Nohara e Maximiano ${ }^{28}$ entendem que "os contratos administrativos têm duração adstrita à vigência dos respectivos créditos, ou seja, correspondente aos exercícios orçamentários. Logo, vigoram até o fim do exercício financeiro em que foram constituídos”.

Em síntese, na visão dos insignes administrativistas, se uma despesa de determinado contrato administrativo não estiver subsumida a quaisquer das exceções contempladas nos incisos do artigo 57 da Lei n. 8.666/1993 (que serão em seguida abordados), ou seja, não se tratar, por exemplo, de um serviço de prestação continuada, como limpeza e vigilância patrimonial, ou projetos contemplados no Plano Plurianual, como obras de prazo mais extenso, qualquer contratação deverá cingir-se ao interregno do exercício financeiro, não podendo o prazo contratual ultrapassar a data de 31 de dezembro do exercício em que celebrado o contrato, de forma a não comprometer o orçamento dos exercícios financeiros seguintes àquele em que contraída a despesa.

Motta $^{29}$ chama a atenção para o fato de que a adstrição dos contratos administrativos ao crédito orçamentário reflete o disposto no artigo 167, I e II, da Constituição Federal, que veda o início de programas ou projetos não incluídos na lei orçamentária anual, assim como a realização de despesas ou a assunção de obrigações diretas que excedam os créditos orçamentários ou adicionais.

Mostra-se relevante abordar as exceções previstas nos incisos I a V do artigo 57 (o inciso III foi vetado), para que se situe de forma mais pormenorizada a regra do crédito orçamentário.

\subsection{As exceções à vigência do crédito orçamentário}

\subsubsection{O Plano Plurianual (inciso I)}

A primeira hipótese tratada no inciso I do artigo 57 como exceção à adstrição ao crédito orçamentário diz respeito “aos projetos cujos produtos estejam

28 MAXIMIANO, Antonio Cesar Amaru; NOHARA, Irene Patrícia. Gestão pública: abordagem integrada da administração e do direito administrativo. São Paulo: Atlas, 2017, p. 306.

29 MOTTA, Carlos Pinto Coelho. Eficácia nas licitações e contratos. 10. ed. Belo Horizonte: Del Rey, 2005, p. 465. 
contemplados nas metas estabelecidas no Plano Plurianual, os quais poderão ser prorrogados se houver interesse da Administração e desde que isso tenha sido previsto no ato convocatório". Trata-se de norma que reflete o disposto no $\mathbb{S} 1^{\circ}$ do artigo 167 da Constituição Federal, que determina que "nenhum investimento cuja execução ultrapasse um exercício financeiro poderá ser iniciado sem prévia inclusão no plano plurianual, ou sem lei que autorize a inclusão, sob pena de crime de responsabilidade".

Ou seja, à luz da norma legal sob comento, um contrato administrativo não só pode ser celebrado com prazo de início de vigência num exercício financeiro com duração estendida até o exercício seguinte como permite prorrogações do prazo para além da data de 31 de dezembro, desde que o objeto contratual esteja contemplado no Plano Plurianual em vigor ${ }^{30}$.

O Plano Plurianual, ou simplesmente PPA, é disciplinado no $\mathbb{S} 1^{\circ}$ do artigo 165 da Constituição Federal, que preconiza que a "lei que instituir o plano plurianual estabelecerá, de forma regionalizada, as diretrizes, objetivos e metas da administração pública federal para as despesas de capital e outras delas decorrentes e para as relativas aos programas de duração continuada". Segundo o artigo $35, \mathbb{} 2^{\circ}$, do Ato das Disposições Constitucionais Transitórias, o PPA possui prazo de vigência de quatro anos, iniciando-se a partir do segundo exercício financeiro do mandato do Chefe do Poder Executivo eleito, estendendo sua vigência até o final do primeiro exercício financeiro do mandato subsequente, ou seja, "no primeiro ano" de exercício de mandato, o Chefe do Poder Executivo eleito estará cumprindo o último ano do Plano Plurianual de seu antecessor.

Os planos plurianuais possuem berço constitucional, integrando um sistema coordenado de normas de caráter orçamentário estampadas no artigo $165^{31}$ da Carta da República, ao lado das leis de diretrizes orçamentárias e leis orçamentá-

30 Destaque-se o entendimento do Plenário do TCU, ao decidir que “(...) com o advento da Lei 8.666/1993, alterada pela Lei 8.883/1994, a vigência dos contratos anteriormente celebrados passou a ficar adstrita aos respectivos créditos orçamentários, com exceção dos projetos cujos produtos estivessem contemplados nas metas estabelecidas no Plano Plurianual, os quais poderiam receber prorrogação, desde que previstos no instrumento convocatório. 22. Portanto, não se tratando de meta expressamente prevista nos respectivos Planos Plurianuais da Prefeitura de (...), o contrato celebrado deveria ter-se cingido ao período relativo aos créditos neles previstos até então. Assim, não se admite, há muito, a contratação por prazo indeterminado ou com vigência injustificavelmente longa" (Acórdão TCU 1.683/2004, Plenário, rel. Min. Augusto Sherman Cavalcanti).

31 “Art. 165. Leis de iniciativa do Poder Executivo estabelecerão: I - o plano plurianual; II - as diretrizes orçamentárias; III - os orçamentos anuais." 
rias anuais, estruturado de forma harmônica e integrado pelas três leis mencionadas e que, segundo Horvath" : “(...) possuem uma relação de coordenação entre si, possibilitando que o plano de ação governamental se estruture de forma coesa e harmônica".

A Lei do Plano Plurianual, ou simplesmente PPA, exterioriza o início das ações do planejamento governamental do Governo eleito, de caráter estratégico, tratando das despesas de capital e outras delas decorrentes e das despesas de duração continuada ${ }^{33}$. E, ao se falar em planejamento governamental, de natureza política, este tem sua juridicização estampada no PPA, ou seja, segundo Conti ${ }^{34}$ :

(...) é nele que deverá estar materializado o plano de governo, explicitando-se as políticas públicas, programas e ações governamentais a serem implantados, continuados, incentivados e desenvolvidos ao longo dos próximos quatro anos”. Ou, de outro lado, também os que serão encerrados, descontinuados e desincentivados. É lá que se verificarão se as promessas de campanha efetivamente estão contempladas e, portanto, aumentando a expectativa de que venham a ser cumpridas e onde se espera encontrar a previsão de quais serão os investimentos públicos e políticas econômicas e sociais.

No entanto, não basta que a despesa esteja contemplada no Plano Plurianual. É preciso que a lei de diretrizes orçamentárias, também de caráter anual, recorte do PPA a parcela do plano a ser implementada dentro do exercício financeiro subsequente, orientando sua inserção no projeto da lei orçamentária anual.

Em razão do fato de que o PPA se estende pelo período de quatro anos, e que parcelas de seus planos serão impressas nos orçamentos anuais, mediadas pela

32 HORVATH, Estevão. O orçamento no século XXI: tendências e expectativas. Tese de Titularidade da Faculdade de Direito da Universidade de São Paulo, São Paulo: edição do autor, 2014, p. 292.

33 Segundo Piscitelli, o PPA “(...) irá se preocupar com um tipo bastante específico de despesa: aquelas cuja execução resulta no aumento do patrimônio líquido da administração (despesas de capital) e aquelas cuja execução ultrapassa o exercício financeiro (despesas de duração continuada). Sendo assim, não é de interesse do PPA disciplinar despesas com o custeio da máquina pública - as chamadas despesas correntes - ou mesmo outros gastos mais triviais da Administração. O que o legislador constitucional pretendeu foi dar à administração a possibilidade de colocar em prática um grande plano de governo, que seria executado por um período relativamente longo: quatro anos" (Direito financeiro. Rio de Janeiro: Forense, 2018, p. 70).

${ }^{34}$ CONTI, José Mauricio. Planejamento municipal precisa ser levado a sério. In: CONTI, José Mauricio. Levando o direito financeiro a sério: a luta continua. 2. ed. São Paulo: Blucher, 2018, p. 105-106. 
LDO, é que o inciso I do artigo 57 da Lei n. 8.666/1993 excepciona a duração do contrato à vigência do crédito orçamentário.

\subsubsection{Os serviços contínuos (inciso II)}

O inciso II estabelece como exceção à regra da adstrição ao crédito orçamentário os chamados serviços de prestação continuada, ou simplesmente serviços contínuos, que são aqueles serviços "a serem executados de forma contínua, que poderão ter a sua duração prorrogada por iguais e sucessivos períodos com vistas à obtenção de preços e condições mais vantajosas para a administração, limitada a sessenta meses".

São aqueles serviços cuja necessidade, para a Administração Pública, é de natureza permanente, tais como limpeza, manutenção de equipamentos, como informática ou elevadores em repartições públicas, vigilância patrimonial de órgãos públicos, dentre outros, não admitindo solução de continuidade.

Justen Filho ${ }^{35}$, em análise deste inciso, traça os seguintes apontamentos:

A identificação dos serviços de natureza contínua não se faz a partir do exame propriamente da atividade desenvolvida pelos particulares, como execução da prestação contratual. A continuidade do serviço retrata, na verdade, a permanência da necessidade pública a ser satisfeita. Ou seja, o dispositivo abrange os serviços destinados a atender necessidades públicas permanentes, cujo atendimento não exaure prestação semelhante no futuro.

Não é a natureza da atividade, mas, sim, a dimensão da sua necessidade para a Administração que define a subsunção ao inciso II. Sendo de natureza permanente, a interrupção de tais atividades pode acarretar sérios prejuízos à Administração Pública, a exemplo dos serviços de limpeza interna em órgãos ou autarquias. Eventual solução de continuidade do serviço, além da acumulação da sujeira, submeteria servidores e cidadãos que acorrem aos serviços do órgão a condições insalubres, o que reflete a necessidade permanente do serviço.

E, sendo de necessidade permanente, referida despesa estará sempre presente nos orçamentos, o que significa dizer que tal previsibilidade afasta a preocupação de que o prazo de vigência contratual, ultrapassando a data de 31 de dezembro, compromete os orçamentos subsequentes ao exercício em que celebrado. Acrescenta Justen Filho ${ }^{36}$ :

35 JUSTEN FILHO, Marçal. Comentários à lei de licitações e contratos administrativos. 16. ed. São Paulo: RT, 2014, p. 949.

36 JUSTEN FILHO, Marçal. Comentários à lei de licitações e contratos administrativos, cit., p. 950. 
A regra da prorrogabilidade não se vincula à importância do serviço, mas à previsibilidade da existência de recursos orçamentários para seu futuro custeio. Lembre-se que o dispositivo do art. 57 vincula-se à disciplina orçamentária. Um serviço contínuo, relacionado com uma necessidade permanente e renovada, poderá ser contratado com previsão de prorrogação porque se presume que sempre haverá inclusão de verbas para sua remuneração no futuro.

Tais serviços não podem ser confundidos com aqueles cuja execução pode se estender no tempo e que, no entanto, uma vez realizados, não são mais necessários para o Poder Público. Um serviço cujo cronograma de execução dure seis meses, por exemplo, não sendo de necessidade permanente, pois sua necessidade se esgota com a realização, não se subsume à hipótese do inciso II, mas do caput do artigo 57.

Por fim, a celebração do contrato não precisa coincidir com o ano civil. É possível, por exemplo, que o contrato seja pactuado pelo prazo de 12 meses, iniciando-se num exercício e findando no subsequente, uma vez que a duração do contrato não se confunde com a condição de comprovação da existência de recursos orçamentários para o pagamento das obrigações executadas no exercício financeiro em curso ${ }^{37}$.

No entanto, estabelece o inciso que a vigência contratual, incluindo suas prorrogações, está limitada ao lapso temporal de sessenta meses, devendo a Administração, na iminência do esgotamento do prazo em questão, já providenciar nova licitação.

\subsubsection{As demais hipóteses dos incisos IV e $\mathrm{V}^{38}$}

A terceira hipótese prevista no inciso IV diz respeito "ao aluguel de equipamentos e à utilização de programas de informática, podendo a duração estender-se pelo prazo de até 48 (quarenta e oito) meses após o início da vigência do contrato".

A hipótese assemelha-se àquela descrita no inciso II, referente aos serviços contínuos, uma vez que a locação de equipamentos e o uso de programas de informática pelos órgãos públicos constituem despesas contínuas, da mesma forma, previstas tanto no orçamento do exercício em que contraídas quanto nos orçamentos subsequentes. A diferença determinante diz respeito ao prazo limite de 48

\footnotetext{
37 TCU, Decisão 586/2002, 2 ${ }^{a}$ Câmara, Rel. Adylson Motta, julgamento em 21/11/2002.

${ }_{38} \mathrm{O}$ inciso III foi vetado.
} 
(quarenta e oito) meses referente à locação ou uso ora mencionados, atribuída à possibilidade de desgaste de equipamentos ou sua obsolescência.

Por fim, a última possibilidade descrita no inciso $\mathrm{V}$, incluída na Lei $\mathrm{n}$. 8.666/1993 pela Lei n. 12.349/2010, referente "às hipóteses previstas nos incisos IX, XIX, XXVIII e XXXI do art. 24, cujos contratos poderão ter vigência por até 120 (cento e vinte) meses, caso haja interesse da administração".

Em síntese, tratam, respectivamente, de hipóteses de contratos celebrados mediante dispensa de licitação para as seguintes finalidades: possibilidade de comprometimento da segurança nacional; compras de material pelas Forças Armadas, para fins de manutenção de padronização; fornecimento de bens e serviços produzidos ou prestados no País e que envolvam alta complexidade tecnológica e defesa nacional; e contratações voltadas aos incentivos à inovação e à pesquisa científica e tecnológica no ambiente produtivo, nos moldes da Lei n. $10.973 / 2004$.

Como a Lei n. 12.349/2010, acima mencionada, resultou da conversão da Medida Provisória n. 495, de julho de 2010, os motivos que fundamentaram a referida MP se centraram no fato de que tais contratações por vezes requerem vultosos investimentos dos agentes privados, sendo, não raro, a compra, pelo Estado, de grandes volumes, viabilizando-se, assim, a infraestrutura de produção privada de caráter estratégico. Dessa forma, a possibilidade da longa vigência contratual garantiria a viabilidade das ações e reuniria condições para assegurar maior efetividade aos recursos públicos alocados em contratos dessa natureza ${ }^{39}$.

\section{A EXECUÇÃO DO ORÇAMENTO E OS RESTOS A PAGAR}

A análise da vigência contratual sob a ótica estrita do caput do artigo 57 da Lei n. 8.666/1993 pode, de fato, levar à conclusão de que, fora das hipóteses de seus incisos, nenhuma contratação poderia estender seu prazo de vigência para além da data de 31 de dezembro do exercício em que contraída a despesa.

No entanto, não se podem olvidar outros fundamentos jurídicos que devem ser considerados no contexto deste estudo, abrindo-se o leque de possibilidades interpretativas.

Um aspecto que não deve ser deixado à parte do debate diz respeito ao instituto dos restos a pagar, previsto no artigo 36 da Lei n. 4.320/1964.

\footnotetext{
39 Disponível em: http://www.planalto.gov.br/ccivil_03/_ato2007-2010/2010/Exm/EMI-104-MPMF-MEC-MCT-MPV-495-10.htm. Acesso em: 4 jul. 2018.
} 
Antes de adentrar nas minúcias do referido instituto, é imperioso que se compreenda a importância do empenho nesse processo enquanto instrumento integrante da execução orçamentária.

O empenho da despesa encontra-se definido no artigo 58 da Lei n. 4.320 como "o ato emanado de autoridade competente que cria para o Estado obrigação de pagamento pendente ou não de implemento de condição”.

Trata-se de ato administrativo que inaugura o procedimento de execução da despesa pública. É preciso relembrar, por oportuno, que, no procedimento de realização da despesa, há uma fase prévia, já mencionada, que diz respeito ao procedimento licitatório, e, caso não haja, é preciso que se instaure, da mesma forma, procedimento administrativo que justifique a dispensa ou inexigibilidade de licitação, atendendo às exigências do artigo 26 da Lei n. 8.666/93 ${ }^{40}$, mormente a justificativa do fornecedor do bem ou serviço, bem como do preço.

Têm-se, portanto, como fases clássicas da despesa: o empenho, a liquidação e o pagamento.

Conforme mencionado supra, o empenho inicia o procedimento da execução da despesa e, na qualidade de ato administrativo de que se reveste, possui efeitos concretos, a saber: 1) nos termos do artigo 58, já citado, cria para o Estado a obrigação de pagamento, pendente ou não de implemento de condição; 2) deduz do crédito orçamentário pertinente o montante de recursos hábeis a integrar a despesa; 3) demonstra ao credor que os valores empenhados encontram respaldo no orçamento, conferindo segurança jurídica.

Acrescenta Lochagin ${ }^{41}$ :

Como ato cuja finalidade principal é reservar recursos para posterior pagamento, o empenho se mostra uma das etapas mais importantes pela qual

40 "Art. 26. As dispensas previstas nos $\mathbb{S} 2^{\circ}$ e $4^{\circ}$ do art. 17 e no inciso III e seguintes do art. 24 , as situações de inexigibilidade referidas no art. 25, necessariamente justificadas, e o retardamento previsto no final do parágrafo único do art. $8^{\circ}$ desta Lei deverão ser comunicados, dentro de 3 (três) dias, à autoridade superior, para ratificação e publicação na imprensa oficial, no prazo de 5 (cinco) dias, como condição para a eficácia dos atos. (...) Parágrafo único. O processo de dispensa, de inexigibilidade ou de retardamento, previsto neste artigo, será instruído, no que couber, com os seguintes elementos: I - caracterização da situação emergencial, calamitosa ou de grave e iminente risco à segurança pública que justifique a dispensa, quando for o caso; II - razão da escolha do fornecedor ou executante; III - justificativa do preço; IV - documento de aprovação dos projetos de pesquisa aos quais os bens serão alocados."

${ }^{41}$ LOCHAGIN, Gabriel Loretto. A execução do orçamento público: flexibilidade e orçamento impositivo. São Paulo: Blucher, 2016, E-book, p. 89. 
passa a despesa pública. Ele evita que o pagamento seja frustrado por falta de verba e ao mesmo tempo possibilita aos diversos órgãos do governo conhecer as diversas parcelas empenhadas da despesa.

Ressalte-se que os $\mathbb{S} \int 2^{\circ}$ e $3^{\circ}$ do artigo 60 da Lei n. 4.320 permitem que o empenho seja feito por estimativa quando o montante da despesa não puder ser determinado, assim como permite tanto o empenho global de despesas contratuais quanto aquelas despesas sujeitas a parcelamento.

Segue-se ao empenho a fase de liquidação, que, segundo o artigo 63 da Lei n. 4.320/1964, "consiste na verificação do direito adquirido pelo credor tendo por base os títulos e documentos comprobatórios do respectivo crédito". Constitui, segundo o artigo 62 da lei mencionada, condição legal prévia ao pagamento.

Nessa fase de liquidação, busca-se verificar a origem, o objeto a ser pago e o credor, tendo a liquidação por base, na forma do $\mathbb{S} 2^{\circ}$ do referido artigo 63 , os comprovantes da entrega de material ou da prestação efetiva do serviço, na forma estabelecida no instrumento contratual.

Encerra-se o procedimento com o pagamento, previamente determinado pelo ordenador de despesas, nos moldes do artigo 64 da lei.

No entanto, é possível que, uma vez tendo a despesa sido objeto de empenho, o pagamento não venha a ser efetivado no exercício financeiro em que contraída. E é diante de tais circunstâncias que a Lei n. 4.320/1964 dispõe sobre o instituto dos restos a pagar e que deve ser considerado no momento de interpretação da norma do artigo 57 do Estatuto das Licitações.

\subsection{Dos restos a pagar}

Dispõe o caput do artigo 36 da Lei n. 4.320/1964:

Art. 36. Consideram-se Restos a Pagar as despesas empenhadas mas não pagas até o dia 31 de dezembro distinguindo-se as processadas das não processadas.

Trata-se, portanto, de despesa cuja realização não se operou por completo dentro do exercício financeiro em que contraída. Os restos a pagar processados são aqueles devidamente empenhados, executados e liquidados, porém não foram devidamente pagos dentro do exercício. Já os restos a pagar não processados são os que foram devidamente empenhados, porém o instrumento contratual ainda não foi inteiramente executado, o que não permitiu sua liquidação dentro do exercício.

O que se observa é que, para que se conceba a inscrição concreta dos restos a pagar, processados ou não processados, a condição sine qua non é a realização 
do empenho prévio no exercício em que contraída a despesa, uma vez que, em função do regime contábil de competência adotado no sistema político brasileiro para as despesas públicas ${ }^{42}$, adotou-se como fato gerador da despesa orçamentária o empenho ${ }^{43}$.

Segundo o magistério de Machado Jr. e Costa Reis ${ }^{44}$ :

(...) A distinção tem efeitos práticos, pois, ao programar o pagamento dos Restos a Pagar, naturalmente a Administração dará prioridade aos advindos das obrigações processadas no exercício anterior, além de servir a um melhor controle da despesa pública. (...)

Em restos a pagar só devem ser inscritas aquelas despesas contratadas e que vão se efetivar no exercício seguinte.

Esclarece Feijó ${ }^{45}$ que

(...) a observância dos requisitos legais para a execução da despesa pública muitas vezes exige o cumprimento de cronogramas que consomem vários meses podendo se estender para exercícios futuros. Assim, ao final de um exercício, se a despesa empenhada ainda não houver sido paga, seu valor será reconhecido como despesa orçamentária, lançando-se adicionalmente o direito do fornecedor em conta de obrigação do governo, a conta "restos a pagar".

Entenda-se despesa orçamentária em relação ao exercício em que contraída. Daí o caráter extraorçamentário dos restos a pagar no tocante ao orçamento do exercício subsequente, ou seja, os restos a pagar não oneram, em tese, o orçamento então em vigor, vez que, conforme Feijó ${ }^{46}$,

42 "Art. 35. Pertencem ao exercício financeiro: (...) II - as despesas nele legalmente empenhadas" (Lei 4.320/1964).

43 "As despesas orçamentárias devem ser consideradas realizadas na data do empenho, tendo em vista o disposto no art. 35, inciso II da Lei n. 4.320/1964. Costuma-se afirmar, em razão disso, que a Lei n. 4.320/1964 adotou o regime de competência para as despesas orçamentárias" (GOMES, Emerson Cesar da Silva. O direito dos gastos públicos no Brasil. São Paulo: Almedina, 2015, p. 77).

${ }^{44}$ MACHADO JR., José Teixeira; REIS, Heraldo da Costa. A Lei 4.320 comentada. 30. ed. Rio de Janeiro: Ibam, 2000/2001, p. 92-93.

${ }^{45}$ FEIJÓ, Paulo Henrique; ALbUQUERQUe, Claudiano; MEDEIROS, Márcio. Gestão de finanças públicas, cit., p. 338.

${ }^{46}$ FEIJÓ, Paulo Henrique; AlbUQUERQUe, Claudiano; MEDEIROS, Márcio. Gestão de finanças públicas, cit., p. 339. 
(...) uma vez que se trata de valor já lançado como despesa em exercício anterior, o seu pagamento constitui um dispêndio "extraorçamentário" (conforme previsto no MCASP), no exercício em que ocorre esse pagamento, e não uma despesa orçamentária, visto que essa já foi devidamente registrada no exercício em que foi empenhada. Portanto, não é demais lembrar, não constará do Balanço Orçamentário do ano em que for pago, pois já integrou o Balanço Orçamentário do exercício em que foi empenhado.

Promovendo-se o cotejo entre as disposições da Lei n. 4.320/1964, especialmente seu artigo 36, que trata dos restos a pagar, com o caput do artigo 57 da Lei n. 8.666/1993, há uma nítida indicação de que, desde que o crédito orçamentário que autoriza determinada despesa num exercício tenha gerado o empenho integral da despesa contratual pertinente, o ordenamento jurídico, sistematicamente analisado (e não isoladamente, a partir de uma norma apenas), permite que contratos administrativos celebrados e iniciados em determinado exercício se estendam, no que tange à execução do objeto, ao exercício financeiro subsequente. $\mathrm{O}$ artigo 36 mencionado traz no sistema orçamentário nacional um mecanismo de flexibilização da rigidez da anualidade orçamentária, considerada por alguns uma modalidade de carry-over, como se explicitará mais adiante.

Com a despesa contratual globalmente empenhada no seu exercício, nada obsta que a execução contratual ultrapasse a data de 31 de dezembro para finalizar no exercício seguinte, pois não haverá o receio de que o orçamento do exercício financeiro seguinte possa vir a ser comprometido.

Considere-se, por exemplo, a contratação de um serviço cujo cronograma de execução seja estimado em 6 (seis) meses, prazo inferior a um exercício financeiro (doze meses). Na hipótese de sua licitação ser concluída no mês de setembro, na visão dos ilustres administrativistas retrocitados, o contrato não poderia ser celebrado, o que pode comprometer o exercício das funções administrativas, dinâmicas que são por natureza.

No entanto, desde que o empenho seja integralmente efetivado, nada obsta que o contrato seja assinado em setembro e concluído em fevereiro do exercício seguinte, devendo do instrumento contratual constar cláusula de vigência com prazo certo (seis meses), a teor do artigo 55, IV, da Lei n. 8.666/1993 ${ }^{47}$, ressaltando a disposição contida no artigo $57, \mathbb{S} 3^{\circ}$, de que é vedado o contrato administrativo com prazo de vigência indeterminado.

47 “Art. 55. São cláusulas necessárias em todo contrato as que estabeleçam: (...) IV - os prazos de início de etapas de execução, de conclusão, de entrega, de observação e de recebimento definitivo, conforme o caso." 
Foi nesse sentido que caminhou o entendimento da Advocacia Geral da União, ao editar, em dezembro de 2011, a Orientação Normativa n. 39, com a seguinte redação:

A vigência dos contratos regidos pelo art. 57, caput, da Lei 8.666, de 1993, pode ultrapassar o exercício financeiro em que celebrados, desde que as despesas a eles referentes sejam integralmente empenhadas até 31 de dezembro, permitindo-se, assim, sua inscrição em restos a pagar.

$\mathrm{O}$ ato normativo citado traz por motivação ${ }^{48}$ o fato de que "a tônica da legislação é garantir o pagamento da obrigação assumida, e a inscrição da despesa em Restos a Pagar, quando necessário, um dos instrumentos para tanto”. Os fundamentos da Orientação sob enfoque sustentam-se, inclusive, no disposto no parágrafo único do artigo $8^{\circ}$ da Lei de Responsabilidade Fiscal, que preconiza que "os recursos legalmente vinculados a finalidade específica serão utilizados exclusivamente para atender ao objeto de sua vinculação, ainda que em exercício diverso daquele em que ocorrer o ingresso", norma esta que se insere no âmbito do Capítulo II da Lei, referente ao planejamento, Seção IV, que trata da execução orçamentária e cumprimento das metas fiscais.

\subsubsection{Dos restos a pagar e as disposições do Decreto Federal n. 93.872/1986}

No âmbito federal, é preciso dar evidência às disposições do Decreto n. 93.872 ${ }^{49}$, de dezembro de 1986 (com alterações posteriores), que dispõe sobre a unificação dos recursos de caixa do Tesouro Nacional. Estabelece seu artigo 35:

Art. 35. O empenho de despesa não liquidada será considerado anulado em 31 de dezembro, para todos os fins, salvo quando:

I - vigente o prazo para cumprimento da obrigação assumida pelo credor, nele estabelecida;

II - vencido o prazo de que trata o item anterior, mas esteja em curso a liquidação da despesa, ou seja de interesse da Administração exigir o cumprimento da obrigação assumida pelo credor; (...)

${ }^{48}$ Disponível em: http://www.agu.gov.br/atos/detalhe/418810. Acesso em: 5 jul. 2018.

49 Os fundamentos de validade do Decreto estão no artigo 84, incisos IV e VI, $a$, da CF, que atribui ao Presidente da República a competência para expedir decretos para fiel execução da lei, bem como disciplinar, via decreto, a organização e funcionamento da Administração Federal, desde que não importe em aumento de despesa, além do artigo 92 do Decreto-Lei n. 200/1967, que diz que "com o objetivo de obter maior economia operacional e racionalizar a execução da programação financeira de desembolso, o Ministério da Fazenda promoverá a unificação de recursos movimentados pelo Tesouro Nacional através de sua Caixa junto ao agente financeiro da União". 
Colhe-se do inciso I da referida norma que, em âmbito federal, encontra-se consolidada a possibilidade de celebração de contrato administrativo num exercício e que estenda sua vigência ao exercício seguinte, fora das hipóteses dos incisos do artigo 57 da Lei n. 8.666/1993, desde que tenha havido o empenho integral da despesa no seu respectivo exercício.

Novamente esclarece Feijó ${ }^{50}$, em análise à referida norma:

No entanto, o texto do decreto não despreza o fato de que nem todos os empenhos não liquidados até 31 de dezembro devem ser cancelados, conforme se pode concluir nas análises a seguir:

Alínea a) - "vigente o prazo para cumprimento da obrigação assumida pelo credor": Trata-se de situação em que, após transcorrido o ano, o contrato continue em vigência e a despesa continue em execução. É o que ocorre, por exemplo, na execução de uma obra, que pode ser contratada em um exercício e somente terminar em exercício futuro. O contrato confere, ao fornecedor, direitos que não se extinguem com o cancelamento do empenho. Por isso, o Decreto preservou esses empenhos. Esse dispositivo é também a admissão de que o governo pode contratar, à conta do orçamento de um ano, despesas que tenham execução prevista para período que ultrapassa o período de vigência do orçamento. Nesse caso, ao final desse exercício a despesa será inscrita em restos a pagar, os quais se manterão vigentes até que o contrato seja integralmente executado.

No que tange aos restos a pagar, observa-se que a Lei n. 4.320/1964 não estabelece prazo para sua duração, não se determinando, pelo menos em patamar legal, o prazo de validade dos empenhos inscritos. Atualmente, no âmbito federal, a questão vem disciplinada no artigo $68, \mathbb{S} 2^{\circ}$, do Decreto n. 93.872/1986 (alterado pelo Decreto n. 7.654/2011), nos seguintes termos ${ }^{51}$ :

Art. 68. A inscrição de despesas como restos a pagar no encerramento do exercício financeiro de emissão da Nota de Empenho depende da observância das condições estabelecidas neste Decreto para empenho e liquidação da despesa. $\$ 1^{\circ} \mathrm{A}$ inscrição prevista no caput como restos a pagar não processados fica condicionada à indicação pelo ordenador de despesas.

$\$ 2^{\circ}$ Os restos a pagar inscritos na condição de não processados e não liquidados posteriormente terão validade até 30 de junho do segundo ano subsequente ao de sua inscrição, ressalvado o disposto no $\mathbb{\$} 3^{\circ}$.

${ }^{50}$ FEIJÓ, Paulo Henrique; ALBUQUERQUe, Claudiano; MEDEIROS, Márcio. Gestão de finanças públicas, cit., p. 359-360.

${ }_{51}$ Disponível em: http://www.esaf.fazenda.gov.br/institucional/centros-regionais/sao-paulo/arquivos/decreto-93872.pdf/view. Acesso em: 5 jul. 2018. 
$\mathbb{S} 3^{\circ}$ Permanecem válidos, após a data estabelecida no $\mathbb{2} 2^{\circ}$, os restos a pagar não processados que:

I - refiram-se às despesas executadas diretamente pelos órgãos e entidades da União ou mediante transferência ou descentralização aos Estados, Distrito Federal e Municípios, com execução iniciada até a data prevista no $\mathbb{S}$ $2^{\circ}$; ou

II - sejam relativos às despesas:

a) do Programa de Aceleração do Crescimento - PAC;

b) do Ministério da Saúde; ou

c) do Ministério da Educação financiadas com recursos da Manutenção e Desenvolvimento do Ensino.

Ou seja, os empenhos inscritos em restos a pagar não processados, na esfera federal, em regra, permanecem válidos por mais um ano e meio a partir de sua inscrição. Diante da omissão legal referente à vigência dos restos a pagar, tais prazos são geralmente disciplinados por ato normativo de cada ente federado.

Por força do artigo 92, I, e do artigo 115, $\mathbb{S} 1^{\circ}$, a, do Decreto n. 93.872/1986, os restos a pagar caracterizam-se como dívida flutuante, que diz respeito a compromissos exigíveis, cujo pagamento independe de autorização orçamentária. No entanto, não obstante de caráter flutuante, alerta Silva ${ }^{52}$ que “(...) os restos a pagar, embora tidos pela lei como dívida flutuante, só o são para fins orçamentários, porque sua inscrição, por si, não dá ainda direito ao recebimento da respectiva importância pelo credor nem a obrigação de pagar por parte da Fazenda". Ou seja, requer, ainda, a devida liquidação da despesa, para posterior emissão da ordem de pagamento.

Por fim, na órbita do planejamento orçamentário da Administração Pública, é preciso que o gestor público considere, no momento de disciplinar os restos a pagar do respectivo ente, a segurança jurídica dos prazos contratuais, assegurando-se ao contratado seu direito ao prazo contratualmente pactuado, para que a obrigação contraída possa ser devidamente realizada, para fins de regular liquidação e pagamento da despesa.

\subsubsection{O carry-over orçamentário e os riscos do endividamento público}

Conforme demonstrado, determinada despesa, devidamente empenhada, e, ao ser inscrita em restos a pagar, permite que a execução orçamentária seja concluída no exercício financeiro seguinte àquele em que contraída a referida obrigação.

52 SILVA, José Afonso da. Orçamento-programa no Brasil, cit., p. 347. 
A referida forma de transferência de créditos orçamentários e déficits entre exercícios financeiros ${ }^{53}$ é melhor apreendida ao se compreender o mecanismo do carry-over, técnica adotada por diversos países como forma de flexibilizar a rigidez da anualidade orçamentária.

Segundo Alves, a rigidez mencionada pode ser flexibilizada por meio de dois mecanismos: as dotações plurianuais e o carry-over (também chamado de carry-forward ou de end-year flexibility). Explica o autor ${ }^{54}$ :

No primeiro caso, as dotações são planejadas ainda na origem do orçamento, com duração plurianual; no caso do carry-over, as dotações, independentemente de sua vigência, podem ser transportadas para o exercício financeiro seguinte, no todo ou em parte.

Segundo Aquino e Azevedo ${ }^{55}$, a flexibilização ou redução da rigidez da anualidade orçamentária mediante carregamentos de crédito e déficit entre exercícios financeiros é praticada desde o ano de 1964, com a publicação da Lei n. 4.320. Acrescentam os autores:

Pela anualidade, os recursos alocados para políticas públicas e outras funções administrativas em um exercício orçamentário deveriam ser gastos durante um período definido de tempo, usualmente um exercício financeiro (...). No Brasil, o exercício de 12 meses do ano civil, apesar de os créditos autorizados para o ano pertencerem exclusivamente a esse exercício, pode ser transposto para o exercício seguinte em quatro formas de carry-over (...). Cada uma das formas tem características específicas de obrigação da divulgação, ajustes automáticos no exercício seguinte que será impactado, momento de ocorrência do gasto, se é ou não computado nos limites da LRF, e de entendimento e atuação do controle externo.

Os dois primeiros são (i) a reabertura de créditos especiais no exercício orçamentário seguinte, que são autorizações de gastos alocados no exercício atual que podem ser reabertos no próximo ano, sem necessidade de nova lei autorizadora; e (ii) o superávit financeiro apurado em balanço, que pode ser

53 Frise-se, fora das hipóteses dos incisos do artigo 57 da Lei n. 8.666/1993, uma vez que a questão que está sob exame é o seu caput.

${ }^{54}$ ALVES, Diego Prandino. Carry-over: a flexibilização do princípio da anualidade orçamentária como indutora da qualidade do gasto público e da transparência fiscal. XVI Prêmio Tesouro Nacional de Monografias, 2011, p. 15.

55 AQUINO, André Carlos Busanelli de; AZEVEDO, Ricardo Rocha de. Restos a pagar e credibilidade orçamentária. RAP - Revista de Administração Pública. Rio de Janeiro, 51(4), p. 580-595, jul./ago. 2017, p. 584. 
utilizado para abertura de créditos orçamentários no ano seguinte. Os outros dois mecanismos são os "restos a pagar": (iii) restos a pagar processados (RPP), que vêm da inscrição de despesas empenhadas e liquidadas, como forma de déficit (déficit carry-over), comprometendo as receitas de exercícios futuros com tais despesas, e (iv) o tradicional carregamento de créditos orçamentários (en-year flexibility), conhecido no Brasil como restos a pagar não processados (RPNP), que são despesas empenhadas mas não liquidadas, o que permite o transporte de saldos do exercício atual ainda não executados (não liquidados) para o exercício seguinte.

Segundo o magistério dos referidos autores, os restos a pagar constituem modalidade de carry-over ${ }^{56}$, não sendo este, por outro lado, o entendimento de Alves, para quem

(...) os restos a pagar não devem ser confundidos com o mecanismo do carry-over. No primeiro caso, os recursos já foram comprometidos a determinado credor. No segundo caso, os recursos são decorrentes de saldos positivos da execução orçamentária, ou seja, são recursos não utilizados e, por isso, passíveis de serem empregados no próximo exercício.

Ainda que não considerados modalidade de carry-over, não há como negar aos restos a pagar a natureza de instrumento flexibilizador ou redutor da rigidez da anualidade orçamentária, legalmente previsto, transportando créditos e dotações para o exercício financeiro seguinte, permitindo a continuidade da execução da despesa, e, conforme já mencionado, tem por premissa o resguardo do direito do credor ao recebimento do valor decorrente do fornecimento de bens ou da realização de serviços ou obras.

Não se nega, por outro lado, que a adoção do sistema de restos a pagar pode, da mesma forma, resultar em problemas para a disciplina fiscal, especialmente os não processados, comprometendo as premissas da sustentabilidade fiscal e da boa gestão pública, quando se torna medida de endividamento público e instrumento de manobras fiscais ou contabilidade criativa.

O uso dos restos a pagar, por ter caráter extraorçamentário e não sendo computado como despesa orçamentária do exercício em que inscrito, acaba por criar um orçamento paralelo àquele em vigor, podendo comprometer as receitas do exercício financeiro subsequente, uma vez que se trata de dívida a ser paga, e o ideal seria que a inscrição em restos a pagar fosse lastreada financeiramente

56 ALVES, Diego Prandino. ALVES, Diego Prandino. Carry-over: a flexibilização do princípio da anualidade orçamentária como indutora da qualidade do gasto público e da transparência fiscal, cit., p. 25. 
com recursos do exercício do empenho da despesa, ou seja, o exercício financeiro anterior.

Segundo Feijó ${ }^{57}$ :

Quando a despesa é inscrita em restos a pagar, sem que seja arrecadada a receita que lhe daria suporte financeiro, seu pagamento somente poderá se realizar mediante utilização de receitas futuras. Ocorre que as receitas estimadas para os exercícios seguintes também são comprometidas, nos novos orçamentos, para a realização de novas despesas. Assim, jamais sobram recursos para o pagamento daquelas despesas que tiverem sido inscritas em restos a pagar em montante superior às disponibilidades financeiras do final do exercício respectivo. Se, nos exercícios seguintes, novamente houver frustração da arrecadação estimada, os resultados prováveis desse processo serão os seguintes:

i) a inscrição de novas despesas em restos a pagar, também não suportadas por saldo de caixa, gerando um processo de contínuo crescimento dos compromissos não respaldados em arrecadação, ou seja, crescimento descontrolado de endividamento e comprometimento das finanças públicas; ou

ii) a não execução das despesas autorizadas no orçamento corrente, para que sobre os recursos financeiros necessários ao pagamento das despesas do exercício anterior. Especialmente em final de mandato, quando são ampliadas as pressões para acomodação das demandas de gasto, essa prática poderia fazer com que o futuro governante deixasse de realizar seu programa de governo para viabilizar o pagamento de compromissos assumidos pela administração anterior.

De fato, ao promover a inscrição, em restos a pagar, de despesas de determinado exercício, especialmente restos a pagar não processados, que estão em processo de liquidação da despesa, sem o devido lastro financeiro, fatalmente deverão ser usados como lastro para seus respectivos pagamentos os recursos arrecadados no novo exercício, podendo comprometer a implementação de políticas públicas constantes do planejamento do exercício corrente, não havendo, por sua vez, exigência legal de que o novo orçamento do exercício seguinte seja adequado para absorver tais despesas.

Destaque-se que o artigo 42 da Lei de Responsabilidade Fiscal determina que é "vedado ao titular de Poder ou órgão referido no art. 20, nos últimos dois quadrimestres do seu mandato, contrair obrigação de despesa que não possa ser cumprida integralmente dentro dele, ou que tenha parcelas a serem pagas

57 FEIJÓ, Paulo Henrique; ALbUQUERQUE, Claudiano e MEDEIROS, Márcio. Gestão de finanças públicas, cit., p. 342-343. 
no exercício seguinte sem que haja suficiente disponibilidade de caixa para este efeito".

Ou seja, exige-se, expressamente, a disponibilidade de recursos financeiros para cobrir restos a pagar apenas para as despesas contraídas nos últimos oito meses do último ano do mandato, como forma de se resguardar o futuro gestor público eleito, ficando em aberto tal exigência para as despesas contraídas nos quatro primeiros meses anteriores aos referidos dois quadrimestres, além dos três exercícios anteriores ao último ano do mandato do Chefe do Executivo.

Crescimento dos restos a pagar é crescimento do endividamento público. Não obstante não se tratar de dívida consolidada, trata-se, conforme demonstrado, de dívida flutuante, compondo o passivo financeiro do ente político e que deverá ser saldado.

Aquino e Azevedo ${ }^{58}$ alertam, inclusive, para a antiguidade de tais créditos, chegando alguns saldos de restos a pagar a durar cerca de 10 (dez) anos no Governo Federal. Acrescentam que “crescimento de saldo de 'restos a pagar' é aumento de endividamento, dado que inscrições são maiores que pagamentos ou cancelamentos dos créditos (...) Ressalte-se que já houve casos de estados que finalizaram o ano com 60\% da receita própria comprometida com RPNP (Paraná, ano 2000)”.

O acúmulo de restos a pagar no âmbito do Governo Federal levou, inclusive, o Tribunal de Contas da União ${ }^{59}$, no ano de 2006, a recomendar à Secretaria do Tesouro Nacional para que envidasse esforços no sentido de que

(...) seja regulamentado o empenho de despesas ao longo do exercício orçamentário para estabelecer critérios mínimos a serem observados quando da emissão de notas de empenho, de modo a reduzir os elevados montantes inscritos em restos a pagar não processados, que comprometam a programação financeira dos exercícios seguintes.

Segundo esclarecimentos do Fundo Monetário Internacional ${ }^{60}$, por meio do trabalho de Flynn e Pessoa, a acumulação de despesas com pagamentos em atraso

58 AQUINO, André Carlos Busanelli de; AZEVEDO, Ricardo Rocha de. Restos a pagar e credibilidade orçamentária, cit., p. 588.

59 TCU - Acórdão 1.039/2006 (Processo n. 007.465/2005-0), Plenário, rel. Min. Valmir Campelo, data da sessão: 28/06/2006.

60 "The accumulation of expenditure arrears by governments can have a serious negative effect on the domestic economy. Control and clearance of arrears have been priority in almost all IMF-supported programs over the past decade" (FLYNN, Suzanne; PESSOA, Mario. Prevention and management of government expenditure arrears. Technical notes and manuals. Washington: International Monetary Fund, 2014, p. 5). 
pode gerar sérios efeitos negativos na economia doméstica das nações, tendo o controle e a transparência dos atrasos sido considerados prioridades em quase todos os programas apoiados pelo Fundo.

Não é por acaso que Aquino e Azevedo ${ }^{61}$ chamam a atenção para o fato de que "apesar do uso abusivo de RPNP ser alertado tanto pelo Tribunal de Contas da União (TCU) quanto pela Controladoria Geral da União (CGU), seu volume no governo federal já começa a competir com o próprio orçamento" 62 .

A questão passa, necessariamente, pela necessidade de um planejamento governamental e orçamentário eficiente e transparente, consubstanciado por premissas de governança pública que assegurem uma administração voltada aos interesses da sociedade e, acima de tudo, sustentável.

Esclarece Camargo ${ }^{63}$ que:

A boa administração dos recursos públicos constitui-se também em verdadeiro direito fundamental decorrente do princípio republicano, qual seja, o direito republicano de que a gestão financeira do Estado seja permanentemente voltada aos interesses da sociedade, envolvendo eficiência, transparência, monitoramento, controle, prestação de contas, responsabilização dos agentes públicos pelos seus atos e participação social.

O que se extrai das reflexões postas neste artigo é que a boa, eficiente e planejada gestão pública não se mostra incompatível com o instituto dos restos a pagar enquanto mecanismo flexibilizador da rigidez da anualidade orçamentária e, em consequência, com a extensão da vigência dos contratos administrativos para além do exercício financeiro em que celebrado, desde que o empenho tenha sido integral e, principalmente, que os restos a pagar tenham sido lastreados financeiramente, evitando-se as condutas irresponsáveis de usar tal instituto como

${ }^{61}$ AQUINO, André Carlos Busanelli de; AZEVEDO, Ricardo Rocha de. Restos a pagar e credibilidade orçamentária, cit., p. 588.

62 A Secretaria do Tesouro Nacional divulgou em janeiro deste ano "o Relatório de Restos a Pagar (RAP) referente a 2018. Foi inscrito para o exercício o estoque de R \$ 155,0 bilhões de RAP, o que representa um aumento de $\mathrm{R} \$ 6,8$ bilhões (4,6\%) em relação à inscrição ocorrida em 2017 (R\$148,2 bilhões). O aumento decorre basicamente do crescimento de $11,7 \%$ de novas inscrições. Embora o estoque de RAP tenha crescido, ele corresponde a 7,0\% do orçamento, o terceiro menor percentual desde 2008”. Disponível em: http://www.tesouro.fazenda.gov.br/-/tesouro-publica-o-relatorio-de-restos-a-pagar-de-2018. Acesso em: 30 jul. 2018.

${ }^{63}$ CAMARGO, Guilherme Bueno de. Governança republicana e orçamento: as finanças públicas a serviço da sociedade. In: CONTI, J. Mauricio; SCAFF, Fernando F. (coord.). Orçamentos públicos e direito financeiro. São Paulo: RT, 2011, p. 772. 
manobras postergadoras da quitação da obrigação e, acima de tudo, de respeito à boa-fé que deve nortear os contratos administrativos, como expressão máxima do princípio constitucional da moralidade administrativa.

\section{CONSIDERAÇÕES FINAIS}

A partir das colocações postas no presente texto, pode-se chegar às seguintes ilações relevantes:

1) O prazo dos contratos administrativos disciplinado no caput do artigo 57 da Lei n. 8.666/1993 é de natureza orçamentária, típica norma de Direito Financeiro e, como tal, deve ser interpretada também à luz do referido ramo do Direito, sistematicamente com as normas da Lei n. 4.320/1964 e outras normas de caráter orçamentário;

2) A norma do artigo 57, ao vincular a duração dos contratos administrativos aos seus respectivos créditos orçamentários, não deve induzir à ideia de que a vigência contratual, se não corresponder às exceções de algum dos seus incisos, restringe-se ao exercício financeiro, pois o crédito orçamentário com este não se confunde, não obstante viger dentro do exercício;

3) O sistema político brasileiro não veda a celebração de contratos administrativos em um exercício financeiro e que estenda sua vigência ao exercício subsequente, fora das exceções do artigo 57, desde que a despesa contratual tenha sido integralmente empenhada no exercício em que contraída, viabilizando-se sua inscrição em restos a pagar, nos moldes do artigo 36 da Lei n. 4.320/1964;

4) A inscrição em restos a pagar não processados tem seus efeitos mantidos na vigência do novo ano orçamentário, posto que constitui mecanismo de flexibilização ou redução da rigidez da anualidade orçamentária, não comprometendo os créditos orçamentários do novo exercício, o que viabiliza a vigência contratual neste período, de modo a possibilitar a execução do objeto pactuado e, por fim, a liquidação e o pagamento;

5) Na disciplina dos restos a pagar não processados, é preciso que a segurança jurídica referente aos prazos dos pactos contratuais da Administração Pública seja observada, mormente pelo fato de que os prazos contratuais constituem cláusula obrigatória nos contratos administrativos.

\section{REFERÊNCIAS}

ABRAHAM, Marcus. Curso de direito financeiro brasileiro. 4. ed. Rio de Janeiro: Forense, 2017. 
ALVES, Diego Prandino. Carry-over: a flexibilização do princípio da anualidade orçamentária como indutora da qualidade do gasto público e da transparência fiscal. Prêmio Tesouro Nacional de Monografias, 2011.

AQUINO, André Carlos Busanelli de; AZEVEDO, Ricardo Rocha de. Restos a pagar e credibilidade orçamentária. RAP - Revista de Administração Pública. RJ, 51(4), p. 580-595, jul./ago. 2017.

BANDEIRA DE MELLO, Celso Antônio. Curso de direito administrativo. 17. ed. São Paulo: Malheiros, 2004.

BURKHEAD, Jesse. Orçamento público. Rio de Janeiro: FGV, 1971.

CAMARGO, Guilherme Bueno de. Governança republicana e orçamento: as finanças públicas a serviço da sociedade. In: CONTI, J. Mauricio; SCAFF, Fernando F. (coord.). Orçamentos públicos e direito financeiro. São Paulo: RT, 2011.

CONTI, José Mauricio. O planejamento orçamentário da administração pública no Brasil. Tese de Titularidade. Faculdade de Direito da USP. São Paulo: edição do autor, 2017.

CONTI, José Mauricio. Planejamento municipal precisa ser levado a sério. In: CONTI, José Mauricio. Levando o direito financeiro a sério: a luta continua. 2. ed. São Paulo: Blucher, 2018.

DI PIETRO, Maria Sylvia Zanella. Direito administrativo. 29. ed. Rio de Janeiro: Forense, 2016.

FARIA, Rodrigo Oliveira de. Natureza jurídica do orçamento e flexibilidade orçamentária. 2009. 287f. Dissertação (Mestrado) - Faculdade de Direito da Universidade de São Paulo, São Paulo, 2009.

FEIJÓ, Paulo Henrique; ALBUQUERQUE, Claudiano; MEDEIROS, Márcio. Gestão de finanças públicas. 3. ed. Brasília: Gestão Pública, 2013. v. I.

FLYNN, Suzanne; PESSOA, Mario. Prevention and management of government expenditure arrears: technical notes and manuals. Washington: International Monetary Fund, 2014.

FONROUGE, Carlos M. Giuliani. Derecho financiero. 2. ed. Buenos Aires: Depalma, 1970. v. I.

FRANCO, António L. de Sousa. Finanças públicas e direito financeiro. 4. ed.

Coimbra: Almedina, 2015. v. I e II.

FREITAS, Juarez. Discricionariedade administrativa e o direito fundamental à boa administração pública. 2. ed. São Paulo: Malheiros, 2009.

GIACOMONI, James. Orçamento público. 17. ed. São Paulo: Atlas, 2017.

GOMES, Emerson Cesar da Silva. O direito dos gastos públicos no Brasil. São Paulo: Almedina, 2015.

HORVATH, Estevão. O orçamento no século XXI: tendências e expectativas. Tese de Titularidade. Faculdade de Direito da USP. São Paulo: edição do autor, 2014. 
JUSTEN FILHO, Marçal. Comentários à lei de licitações e contratos administrativos.16. ed. São Paulo: RT, 2014.

LEITE, Harrison. Manual de direito financeiro. 6. ed. Salvador: Juspodivm, 2017.

LOCHAGIN, Gabriel Loretto. A execução do orçamento público: flexibilidade e orçamento impositivo. São Paulo: Blucher, 2016. E-book.

MACHADO JR., José Teixeira; REIS, Heraldo da Costa. A Lei 4.320 comentada. 30. ed. Rio de Janeiro: Ibam, 2000/2001.

MAXIMIANO, Antonio Cesar Amaru; NOHARA, Irene Patrícia. Gestão pública: abordagem integrada da administração e do direito administrativo. São Paulo: Atlas, 2017.

MOTTA, Carlos Pinto Coelho. Eficácia nas licitações e contratos. 10. ed. Belo Horizonte: Del Rey, 2005.

NIEBUHR, Joel de Menezes. Licitação pública e contrato administrativo. 2. ed. Belo Horizonte: Fórum, 2011.

PEREIRA JUNIOR, Jessé Torres. Comentários à lei das licitações e contratações da administração pública. 8. ed. Rio de Janeiro: Renovar, 2009.

PISCITELLI, Tathiane. Direito financeiro. Rio de Janeiro: Forense, 2018.

SILVA, José Afonso da. Orçamento-programa no Brasil. São Paulo: RT, 1973.

SLOMSKI, Valmor; PERES, Ursula Dias. As despesas públicas no orçamento: gasto público eficiente e a modernização da gestão pública. In: CONTI, José Mauricio; SCAFF, Fernando Facury (coord.). Orçamentos públicos e direito financeiro. São Paulo: RT, 2011

TORRES, Ricardo Lobo. O orçamento na Constituição. Rio de Janeiro: Renovar, 1995.

VIANA, Arizio de. Orçamento brasileiro. 2. ed. Rio de Janeiro: Edições Financeiras, 1950. 
